\title{
COUNSELS OF PERFECTION AND REFORMATION POLITICAL THOUGHT*
}

SARAH MORTIMER

Christ Church, University of Oxford

Running head: Counsels and Political Thought

Abstract: The debate over counsels of perfection was a crucial aspect of the formation of political and ethical thought in the sixteenth century. It led both Protestants and Catholics to consider the status of law and to consider how far it obliged human beings, rather than simply permitting particular actions. From Luther onwards, Protestants came to see God's standards for human beings in absolute terms, rejecting any suggestion that there were good works which were merely counselled rather than commanded, and therefore not obligatory. This view of ethics underpinned the Protestant theological critique of Catholic doctrines of merit but it also shaped the distinctively Protestant account of natural law. It enabled Luther and his allies to defend magisterial control over the church, and it also formed a crucial element of Protestant resistance theory. By examining the Lutheran position on counsels, expressed in theological and political writings, and comparing it with contemporary Catholic accounts, this article offers a new perspective on Reformation theology and political thought.

Luther's influential text On secular authority (1523) begins with a denunciation of counsels of perfection, a statement which would be crucial for the development of Protestant political thought. ${ }^{1}$ From Luther onwards, Protestants came to see God's standards for human beings in absolute terms, rejecting any suggestion that there were 'counsels of perfection', or good works which were optional rather than obligatory. Counsels of perfection were usually associated with the monastic vows of poverty, chastity and obedience, but in this text the focus of Luther's critique was on the 'counsel' of 
non-resistance, Jesus' call in Matthew 5:39 to 'turn the other cheek', therefore extending the concept of counsels beyond the cloister and into the political arena. This view of ethics, in which all good works must be duties and not merely counsels, underpinned the Protestant theological critique of Catholic doctrines of merit and of Indulgences, but its significance extended beyond the purely theological. In particular, it shaped the distinctively Protestant account of natural law, enabling Protestant writers to describe actions which had formerly been seen as merely permitted or allowed as binding obligations. Not only did this help Luther and his allies to defend magisterial control over the church, but it also formed a crucial element of Protestant resistance theory. Despite the large body of literature on Protestant political thought of the period, however, historians have not explored the implications of this aspect of Luther's writing. ${ }^{2}$ Yet, as this article will show, an examination of the Lutheran position on counsels offers a new perspective not only on Lutheran theology and political thought, but also on the wider sixteenth century debate about the meaning and value of natural law.

The lack of any significant engagement with Protestant views of counsels of perfection by historians of political thought is striking. In one of the few explicit discussions of the political implications of the rejection of this concept of counsels, Michael Baylor notes that the Reformers were faced with an 'especially acute difficulty' in explaining the legitimacy of warfare and punishment, but offers only a short comment on the solution they offered..$^{3}$ Meanwhile, there is a growing interest in the theory of counsel as political or religious advice, as a means of encouraging rulers to act in a virtuous and effective way. ${ }^{4}$ In part the neglect of counsels of perfection can perhaps be explained by a widespread assumption that they are theological rather than political, that Luther's critique of them was part of his campaign to change the doctrines of the church and to eliminate the conceptual foundations of church teaching on indulgences, merit and monasticism. ${ }^{5}$ Although some scholars have noted that Protestant objections to the Catholic doctrine of merit might have wider consequences, in that they entailed a rejection of any kind of ethical theory in 
which good actions might be recommended rather than commanded, these consequences have rarely been explored. ${ }^{6}$

Yet historians have long been interested in the theories of rights developed by Protestants in the sixteenth-century, assuming that these rights are positive, moral claims that cannot be renounced or yielded. In Quentin Skinner's highly influential Foundations of Modern Political Thought, for example, the shift to 'a moral right (and not merely a religious duty)' to resist a tyrannical ruler is described as 'the epoch-making move' which ushers in modern political thought. ${ }^{7}$ Underlying this claim is a strong assumption that a right, or at least a 'moral right', exerts a powerful claim upon the rightholder, who ought, in some sense, to put it into practice. More recent discussion of Protestant ideas of rights has maintained this strong sense of the normative value of rights; nowhere is this clearer than the work of John Witte, whose Reformation of Rights tells 'the human rights side of the Calvinist story'. ${ }^{8}$ He connects sixteenth-century claims about rights to the concept of rights as moral entitlements common in twentieth-century human rights discourse, implicitly rejecting any suggestion that it might be praiseworthy in some situations to forgo or renounce a right. Even those historians who have drawn some attention to the distinction between rights of self-defence and duties towards God, have said little about the implication of this distinction for the value of such rights within the Protestant tradition. ${ }^{9}$ Yet the process by which rights acquired this moral, normative character remains poorly understood; and one way of approaching it is, it will be suggested, through the debate about counsels of perfection.

It is clear from the opening pages of On secular authority that Luther saw the issue of counsels as highly relevant to politics. Initially he dealt with this topic as part of his analysis of the Catholic clergy's challenge to the authority of princes, as he explained in the preface. In some ways the preface struck a different tone to the rest of the book, which - written in response to George Duke 
of Saxony's edict prohibiting the buying and selling of Luther's translation of the New Testament emphasised the limitations of secular authority in spiritual affairs. ${ }^{10}$ But Luther clearly saw the preface as an important component of the overall text, a place to assert not only the legitimacy of secular authority but also its relationship to the clergy. In the preface he claimed he had written the work at the request of those troubled by 'Christ's words in Matthew 5: 'resist not evil ... but be compliant with your opponent, and the person who takes your coat, let him also take your cloak'. These verses seemed to imply that it was impossible to be a Christian and also to uphold property rights or civil order, and Luther suggested that the 'sophists at the universities' had seen this as problematic. Their solution was to teach that 'these sayings of Christ are not commands, but merely "counsels of perfection"'. For Luther, however, this claim was 'neither true nor right'; moreover, this 'poisonous error' had enabled the clergy to exalt their own estate as the followers of Christ's highest principles, claiming they were the only ones capable of fulfilling true Christian ethics and receiving God's favour. The 'imperfect estate' of secular authority was thereby reduced in status, cut off from the highest ethics of Christianity because it engaged in punishment and violence. Secular authority was now 'made ... over wholly to the pope', because of his superior perfection. For Luther, the whole concept of counsels was not only detrimental to Christian doctrine, but it had devastating consequences for political power. If secular authority was to be understood aright, Luther argued, the first task must be to dismantle the Catholic view of counsels of perfection. ${ }^{11}$ Luther's passion is evident, but his train of thought is far from straightforward, which may explain why modern commentators have shied away from engaging with it. He took Christ's words in the Sermon on the Mount, on non-resistance and non-violence, as his paradigm example of a passage which had wrongly been seen as counsel. He argued that it was this kind of Biblical interpretation which had laid the foundation for the great distinction in Christendom between the clergy and the laity, and had ensured that lay Christians can never achieve the kind of spiritual standards of the religious. Much of his own theology was then driven by the quest to root out the doctrine of counsels, and to show that all are equally obliged to obey the laws of God and Christ. 
Few of his contemporaries actually saw counsels of perfection in the way that Luther claimed, but his aversion to counsels as he understood them would exercise a decisive influence on Protestant political thought, driving a deep wedge between Protestant and Catholic thought that would persist through most of the sixteenth century.

By associating counsels with non-resistance, particularly Jesus's words in Matthew 5, Luther and his allies forged a connection between his own theology and the demands of political life. But his Catholic contemporaries and predecessors tended instead to link counsels of perfection with the demands of clerical and monastic life, seeing poverty, chastity and obedience as the three central counsels, most useful in enabling men and women to withdraw themselves from the world and devote themselves to attaining their eternal end. Because Luther's critique of counsels took in not only these three standard ideals, but any kind of alternative Christian ethics, it did not merely undercut the rationale for the church as a separate institution, but it fused together natural and divine positive laws. According to Luther, there could be no separate set of Christian ethics or Christian principles; there was one single ethical standard for human life and that was the divinely given law. ${ }^{12}$

In On secular authority, Luther charged the 'sophisters' with describing Matthew 5:39 as a counsel of perfection, but this was not the most obvious nor the most common Catholic position. It is true that faced with the radical demands of some of Jesus's words, like 'love your enemies', the Church had found it necessary to offer some explanatory glosses. In his great Summa Theologica, the thirteenth century Dominican Thomas Aquinas had argued that Christ only meant that people should always be prepared in their mind ('in anima') to do good, but that actually putting this into practice and actively helping an enemy was only obligatory when it was strictly necessary. But Aquinas wanted to balance the thought that there was merit in helping an enemy with his desire to show that warfare and violence was the right course of action in some circumstances. Thus, commenting on Matthew 5.39 (turn the other cheek) in his discussion of war, Aquinas explained that these 'precepts ... should always be borne in readiness of mind, so that we be ready to obey them, 
and, if necessary, to refrain from resistance or self-defence.' But he added that 'Nevertheless it is necessary sometimes for a man to act otherwise' if the common good or the good of an enemy demanded it. ${ }^{13}$ Jesus' words were not a counsel of perfection, but a precept applicable in different ways to different kinds of circumstances - a position held by leading theologians in the early sixteenth century. ${ }^{14}$

Instead, when medieval theologians discussed counsels of perfection, they usually had in mind the ideals of poverty, chastity and obedience to which the religious aspired. Aquinas himself had presented these as the three central counsels, most useful in enabling men and women to withdraw themselves from the world and devote themselves to attaining their eternal end. He argued that it was most praiseworthy to bind oneself to these counsels by way of a vow, and that by making such a vow a person placed themselves in a 'state of perfection' (status perfectionis) although he accepted that being in such a state was very different from actually being perfect. ${ }^{15}$ Aquinas's comments did foster a connection between obeying the counsels and taking religious vows, suggesting that the counsels - and therefore the highest standards of Christian life - were appropriate only for the religious and not for ordinary Christians, but few people wanted to imply that these counsels undermined the role and authority of civil power.

The Church's position on counsels was clarified a century before Luther's challenge, thanks to Friar Matthew Grabow of Wismar in Saxony. In 1410s Grabow produced a tractate denying that lay people could fulfil the counsels; he even argued that it was in fact a sin for a layperson to try to live without property. This was not only a statement of the superiority of the religious, but a suggestion that civil authority, weighed down by property, was necessarily compromised by its worldly entanglements. His comments, especially about property, were highly controversial and even provoked discussion at the Council of Constance. Asked to comment on Grabow's claims, the leading French theologian Jean Gerson condemned them forcefully. He denied that marriage or the ownership of property excluded a person from the perfect Christian life and explained that the Christian religion was the same for all people, lay or ordained. Grabow was condemned in May 
1419 and the Church's position on these counsels (of poverty, chastity and obedience) was made clearer. $^{16}$

To see why Luther thought that his opponents viewed non-resistance, rather than poverty, chastity and obedience, as paradigmatic counsels, we need therefore to look more carefully at the specific background to his claim in On secular authority. From at least 1512 Luther had been working out the implications of an understanding of divine law which was prescriptive rather than permissive, an understanding of law which ruled out any kind of counsels distinct from commands. Preaching on Matthew 7.12, (do unto others... ), for example, Luther told his audience that 'we are held under God's command to do this as far as we are able to others also when they are in need.' Here he challenged what he saw as the common scholastic reading, from Augustine via Aquinas, that it was sufficient merely to wish the other well in our hearts. To him this was a travesty of the divine message which provided far too many excuses for inaction. ${ }^{17}$ Luther continued to develop his opinions upon these questions and in his Explanations of the ninety-five theses he returned to the issue again. After long sections directed against the papacy, there was a passage at the end in which he claimed that his purpose was not to resist the decrees and decisions of the papacy, and in which he claimed he would submit - albeit in terms which were hardly flattering to Rome. The passage read:

"If anyone strikes you on the right cheek, turn to him the left also" [Matt. 5:39], and in Rom. 12[:19], "Never avenge yourselves, etc." If this were only advice (since even many theologians appear to err), then by this same freedom it should be just as permissible to resist the pope when he inflicts his burdens and unfair decrees, as it is to resist the Turk or other adversaries. But one must not resist anyone, even if one does not approve his action, so that one does not act against one's conscience. But this matter, which is very essential, demands more time and another work. ${ }^{18}$ 
Here Luther introduced a claim about Christian non-resistance, but non-resistance to the papacy rather than the secular authorities. The argument is, however, quite opaque: it seems that Luther is placing resistance to the papacy on the same level as resistance to the Turks, and condemning both of these equally. Even from the passage itself it is evident that Luther could see there was still work to be done in thinking through the implications of his understanding of divine law.

Luther returned to the subject as part of his dissection of the legitimacy of monastic vows, written in 1521 and published the following year as The judgment of Martin Luther on monastic vows. Here he was anxious to show not only that poverty, chastity and obedience were not in fact counsels, but also to get away from any reading of the gospel which focused on counsels and precepts. The problem with those who defended monastic vows was that 'they do not know what the gospel really is (because they make precepts and counsels of it)', distinguishing between precepts which were commanded to all people and counsels which applied only those of superior spiritual status, like the monks. ${ }^{19}$ Such men failed to see that the gospel was not a system of ethics but instead the promises of God to his people. ${ }^{20}$ Luther's energies in this tract were largely taken up with dismantling the basis for monastic vows and denying the superiority of virginity over marriage. But he also remarked that his enemies made the teaching of Christ in the Sermon on the Mount a series of counsels, including here 'not to take revenge, not to return evil for evil, not to go to litigation in court' and so on. ${ }^{21}$ Luther's critique of counsels and of monasticism was thus broadening out into a wider re-interpretation of Christian ethics, centred upon the Sermon on the Mount.

While writing this tract, Luther corresponded with his friend and collaborator Philip Melanchthon, who soon added his voice to the assault upon counsels. ${ }^{22}$ Melanchthon dedicated a section in the 1521 Loci communes to the issue in which he accused the 'Sophists' of false teaching when, 'for the most part, they derive the counsels from Matthew 5, 'Love your enemies, do not resist evil...'. Melanchthon's account here was designed primarily to break down the Catholic distinction between those who had taken religious vows and those who had not, but he added that through this teaching on counsels 'a most unhealthy view has been promulgated, namely, that 
public affairs cannot be administered according to the gospel. ${ }^{23}$ From this point, the political aspect of the critique of counsels would grow in prominence and it would become integral to developing Protestant views of magisterial authority.

By 1521 the Lutheran position on counsels had already provoked the ire of Catholic divines. It had been condemned by the theologians of Louvain in a list of Luther's errors sent in 1519 to Adrian of Utrecht, soon to be Pope Adrian $\mathrm{Vl}^{24}$ when the theology faculty of Paris issued a document condemning the sections of Luther's theology which they found most objectionable they amplified the critique. Under the heading 'Concerning Evangelical Counsels' they said:

[Quoting Luther:] Those words of Christ in Matthew V 'Who strikes you on the right cheek $\& c^{\prime}$ And those to the Romans XII 'Do not avenge yourselves, beloved \&c' are not counsels, as many Theologians seem to err [in saying], but precepts.

This proposition is false, making the law of Christ far too onerous, and runs counter to the scripture rightly understood. ${ }^{25}$

The Parisian divines seem not to have grasped Luther's meaning in the original text, and at first glance the condemnation seems rather odd. But the Parisians must have seen that Luther had touched on one of the central issues of the 1510s: the relationship between God's positive laws and particularly Jesus's teaching in the Sermon on the Mount - and the laws and norms necessary for human life here on earth. If they hoped to persuade Luther of the value of counsels they failed, for it was in response to this condemnation that Luther spelled out, in On secular authority, the fuller implications of his rejection of counsels, challenging some of the central tenets of Catholic thinking.

II

The Parisian divines were not the first to object to Luther's views on counsels, but they seem to have been especially troubled by Luther's comments in the Explanations of the ninety-five theses. Their 
reaction can perhaps be explained by the events of the 1510s, when the French king Louis XII called a Council to put pressure on Pope Julius II. This Council, which met at Pisa, was poorly attended and fizzled out in failure, but not before the University of Paris had been commissioned to write tracts in support of the French position. The Parisian argument turned, as is well known, on the duty of all people and all communities to preserve themselves, a duty which applied no less to the church than it did to any secular or civil community. ${ }^{26}$ As Francis Oakley has pointed out, the defenders of Pisa, especially Jacques Almain and John Mair, appealed to natural law to make their case, and did so in a more thoroughgoing way than any of their predecessors in the conciliarist tradition. ${ }^{27}$ For this reason, the writings of Almain and Mair have been the object of significant scholarly attention ever since the foundational study by John Figgis in 1907, especially among historians of political thought who have shown the influence of their ideas on later accounts of political life. ${ }^{28}$ But Almain's lengthy efforts to defend the claim that self-preservation was in fact a binding duty, and his evident awareness of the tense relationship between this claim and his understanding of Christian ethics, have received less attention.

Defending the Council of Pisa, Almain stressed the authority and the force of natural law as part of his claim that communities and individuals have a duty to preserve themselves. For him, this duty applied not only to secular communities but also - perhaps even especially - to the community of the church. It was incumbent upon the church to protect itself from a pope bent on its destruction, as he outlined in his Questions at vespers, the most succinct of his pro-Pisan tracts. ${ }^{29}$ But his interest in the duties of preservation applicable to individuals and communities comes out even more clearly in commentary he wrote on William of Ockham's Octo questiones on papal power. Here, in a detailed account of the scope and valence of the natural right of self-preservation, he emphasised that if a person were unjustly condemned to death then 'by natural law [iure naturali] he is bound to preserve his own life as much as he can, using licit means'; indeed, if he did not then he 'sins against the natural law by which he is bound to preserve his own life as much as he can'. ${ }^{30}$ Almain rehearsed a number of scenarios along these lines and rejected alternative views, such as 
that of the great French conciliarist Jean Gerson who had argued that a person could choose to remain in prison because of their sins. For Almain, if it were licit - that is, not specifically sinful - for the person to flee then he or she was obliged to do so, by the law of nature. ${ }^{31}$

Yet even Almain admitted that the duty of self-defence could not be fully absolute. During his discussion he brought up the problem of martyrdom, raising the objection that according to his own reasoning the martyrs would have been obliged to flee rather than allow themselves to be killed. He responded that when flight might lead to 'scandal' and undermine the faith, a person is not obliged to flee - suggesting that they were able to act meritoriously in allowing themselves to be killed..$^{32}$ His colleague John Mair faced a similar dilemma in his commentary on Matthew's gospel; this text is usually remembered for its strong defence of the conciliarist case but it also contains long reflections on a range of theological and political issues. Discussing the Sermon on the Mount, Mair argued that it was indeed permissible to kill in self-defence, for 'one is obliged to love oneself more than one's neighbour.'33 This could not, however, be a hard and fast rule for all cases and he still accepted that martyrdom was a possibility for Christians. Like Almain, he highly valued the command to preserve oneself and to love oneself, and not least because it helped to ground his conciliarist case. But he acknowledged that this command could not be absolutely binding and that in some times and places a person could licitly allow themselves to be killed. ${ }^{34}$

It is difficult to know how far these concerns about natural law affected the Parisian divines in 1521 , for by the time the theology faculty of Paris was asked to comment on Luther's theology, Almain was dead and Mair had returned to Scotland. It was their colleagues and successors who were responsible for drawing up the condemnation and they responded in a somewhat different way to Luther's claim than Almain or Mair might have done. Whereas Almain and Mair had sought to limit the scope for non-resistance by stressing the binding duty of natural law, their successors chose instead to reaffirm the distinction between counsels and commands and to give that distinction a political meaning by linking it to the issue of resistance, suggesting that defence of one's self and one's goods was permissible (rather than obligatory). It is noticeable that the Parisian 
divines did not want to suggest that the doctrine of counsels was important for the maintenance of the church's authority, although elsewhere in the document they were keen to assert the reality of ecclesiastical jurisdiction. ${ }^{35}$ By casting counsels as an ethical issue, which helped make Christianity bearable for ordinary people, the Parisian divines of 1521 ran counter to the spirit, if not the letter, of Almain and Mair's writing. Later Catholic writers would continue the line of thought evident in the Parisian condemnation, highlighting the permissive dimension to natural law and noting the conditions under which rights of self-defence might be renounced. Ultimately, it was the Protestants, rather than the Catholics, who would come to emphasise most strongly the obligations of the natural law.

Whatever the Parisian divines intended, to Luther their comments seemed to be a prime example of the clergy trying to defend their exalted estate with an erroneous view of the Christian message. Indeed, it seems to have been this Parisian condemnation which encouraged Luther to connect, in a more systematic way, his thinking about counsels, resistance and ecclesiastical power. Luther now associated the Parisians with the claim that secular powers could not be truly Christian because they involved themselves in coercion and punishment. As we have seen, this was hardly Parisian orthodoxy - and the ongoing commitment at Paris to Almain in particular can be seen from the many editions of his writings, including five editions of his Moralia between 1510 and $1525 .{ }^{36}$ To Luther, however, this sentence in the condemnation offered an excellent example of the clergy describing the Christian message in terms of counsels, refusing to see the radical and total nature of Christ's commands, to all people. From On secular authority onwards, Luther associated the concept of counsels of perfection, with the different - even if related - claim that human ethics and thus human jurisdiction could be divided into an inferior natural and a superior spiritual sphere.

Although the Parisians had no desire to defend Christian pacifism, there were others in the 1520s who did believe it was wrong for a Christian to take up arms and Luther's preface to On Secular Authority suggests a connection in his mind between these positions. The most prominent critic of war was Desiderius Erasmus, whose short essay Dulce bellum inexpertis ('War is sweet to 
those who know it not') contained a forceful attack upon contemporary belligerence. ${ }^{37}$ Moreover there was a long tradition of Christian pacifism which had relatively recently been revived by John Wyclif, who had specifically set the laws and duties of Christians in opposition to the laws of nature. ${ }^{38}$ In 1523 Luther therefore took the opportunity to show he was no anarchist and to explain why his view of Christian theology strengthened magisterial power. The text was an effort to justify his strong doctrines of good works, faith and merit by showing that they are still compatible with a secular order ordained by God to punish the wicked and protect the just. Though Christians have no need of the sword or laws, he argued, the world does, and the Christians' duty to the world means that they must be willing to serve their neighbour through these institutions. ${ }^{39}$ A Christian should therefore treat his own self and goods in one way, and those of his neighbour in another, eschewing resistance for his own sake, but doing so for his neighbour. All these actions are commanded by God's single, undivided law of love which did not admit of counsels. Christians may be free to worship God without the imposition of ceremonies or religious practices upon their conscience, but they were not free to neglect the ethical duties of love.

At the end of the work, Luther emphasised the connection between the law of love and natural law. To him, these were identical: 'nature teaches the same as the law of love: I ought to do what I would have done to me'. ${ }^{40}$ This law of love was understood in a maximalist sense; from his earliest sermons Luther had insisted that human beings are obliged to be perfect though they will inevitably fall short. Of course, no human being could fulfil this law, but God chose to save people through faith and not through performance of external actions. In On secular authority, Christian magistrates were tasked with the heavy, indeed impossible, responsibility of fulfilling this law of love - a responsibility common to all Christians whether lay or ordained.

Through On secular authority, Luther hoped to establish more firmly the power and authority of magistrates, especially against what he saw as the undermining of their estate by the clergy, and to show the connection between his view of political power and the law of God. The consequences for the political thought of the Reformation were profound, more profound than 
Luther had perhaps anticipated or expected. For his claim that God's law demanded one absolute standard would distance the thought of his movement from that of mainstream Catholicism and it would come to characterise some of the most dramatic and influential works of Protestant resistance theory. The implications of Luther's maximalist account of divine (and natural) law would not have been immediately apparent, but his distinctive position on law would later prove important in defending the Reformation.

By the late 1520s Luther's efforts to cultivate princely support had born fruit and rulers across Germany had taken up his cause. Soon they were beginning to redesign their churches in broad accordance with Luther's theological principles. This was not uncontroversial, however, and criticism of the use of secular power to promote religion began to be heard from within the Lutheran movement. In response, some of Luther's colleagues and allies began to explain more clearly why the magistrate should do this, and in the process the connection between divine law and prescriptive natural law was further cemented. This connection would later prove central to Protestant political thought, for it would enable Philip Melanchthon and other Lutherans to justify the resistance they found themselves engaged in once the Emperor mustered his forces against them.

The first city in which the authority of the ruler over religion was challenged was the Imperial free city of Nuremberg. ${ }^{41}$ Here the councillor Lazarus Spengler received an anonymous memorandum in 1529 which claimed that civil authorities should not use coercive power to uphold religion. He forwarded it to a number of leading theologians to obtain their advice and support for the city's campaign against Catholic 'idolatry'. Two of these theologians, probably Andreas Osiander and Wenzeslaus Linck, offered lengthy defences of the city's policy and they did so in part by appealing to Luther's view of the divine law put forward in On secular authority. One of them - it is unclear who wrote which memo - explained that because 'each government is bound by God's command to love God with all its heart, all its soul and all its might, and its neighbour as itself, it is 
equally obligated to use its office to the glory of God' and thus to promote the true religion. ${ }^{42}$ The role and duty of government was thus being described in terms explicitly analogous to the individual Christian and government was now held to the same absolute standard. The other theologian argued along similar lines, noting that 'Christian love demands that a government, by its power or sword, should establish Christian doctrine as much as possible'. ${ }^{43}$ Just as every Christian ought to do their utmost to fulfil the law, then government ought also to promote virtue and true religion in every way possible. For these Protestants, unlike their Catholic counterparts, there was no natural law or natural end separate from divine law - and they refused to acknowledge any counsels above or beyond that law.

The political implications of this Lutheran argument were revealed during the 1530s. After the 1529 Diet in Speyer, a handful of princes had refused to accede to the Emperor's strictures to end their association with Luther, and their 'Letter of Protestation' earned them the name Protestants. The following year these princes, along with representatives of the 'free cities', presented a set of Lutheran religious articles at the Diet of Augsburg, which became known as the Augsburg Confession. Charles V would not acknowledge the validity of these, prompting the princes and cities to band together in a defensive alliance known as the Schmalkaldic League. Fortunately for them, Charles was too busy fighting the French in Italy and the Turks on his Eastern borders to do very much about this group for the time being, but it was rapidly becoming clear that military conflict was on the horizon. ${ }^{44}$ The Lutheran theologians were now placed in a dilemma, forced to contemplate the necessity of armed resistance to the Emperor. From the 1530s, both Luther and Melanchthon began to explore ways in which they might defend the gains they had made, without compromising on their core theological principles. In this tense situation, Luther's rejection of counsels and his insistence on the prescriptive character of the divine law provided crucial intellectual resources for the Protestants.

It is well known that to defend their actions the Lutherans invoked the principle (found in Roman law) that 'it is permitted to repel force with force' (vim vi repellere licet)..$^{45}$ In the Digest it 
was said that this principle was conferred by nature, and so it could also be seen as part of natural law, independent of any specific civil law arrangements. The Imperial law of the Holy Roman Empire seemed to confirm this view, permitting self-defence when there was no other available remedy, for example when a person was attacked by bandits or robbers. This kind of defence was not permitted against the Emperor himself, however, leading some of the Reformers to argue that the Emperor had forfeited his office and become a 'private person'. Others, like Melanchthon, preferred to emphasise the magistrate's responsibility for repelling unjust force. ${ }^{46}$ In both cases, the importance of this principle is clear, and yet the Roman law explicitly used the verb licere, the language of permission, and merely 'licet' defence was difficult to explain within a Lutheran theology in which all good actions must, by definition, be obligatory. In arguing that self-defence was part of a natural law which was in no way permissive, Melanchthon and later Protestants were reshaping the concept and scope of natural law, distancing it in significant ways from the Catholic version developing at the same time.

For all the scholarship on Protestant resistance theory, the connections between the development of the principle of self-defence and the specific contours of Lutheran theology have never been fully explored. Instead, scholars have preferred to examine the constitutional questions raised by discussion of who could exercise this duty, linking it to the development of a theory of resistance based around inferior magistrates. In particular, Diethelm Böttcher and Robert Von Friedeburg have shown that Melanchthon and others were careful to restrict its use to magistrates rather than ordinary, private people. ${ }^{47}$ But what is perhaps most striking about the principle of 'vim $v^{\prime}$ is that, because it became connected to the Lutheran view of law as prescriptive, it generated not only a natural law right of resistance, but a duty that was simultaneously both Christian and natural.

The connection between self-defence and Lutheran theology can be seen from Melanchthon's Philosophiae moralis epitome (1538). In this work he set out a series of natural laws, which he described as 'ideas impressed into the minds of men from heaven, and inborn in us, that is, certain judgements about morals which are a kind of light to the mind'. ${ }^{48}$ One of these laws stated 
that 'the defence of humankind is necessary' and so 'force may be repelled by force, at least in legitimate defence' ${ }^{49}$ Melanchthon later made the point even more explicitly in his Loci praecipue theologici (1559); here he made clear that he saw defence according to natural law was part of Christian duty. The principle 'vim vi liceat repellere' does not contradict the gospel, or Jesus's command to 'love your enemies', he wrote, 'because the gospel does not abolish natural law (ius naturae) or the bonds of political societies, which are laws consonant with right reason'. Here, what Melanchthon wanted to do was intensify that Roman law maxim, so that defence was not merely permitted or licit, but obligatory. Thus, he continued, 'the head of a household (paterfamilias) ought to defend his wife and children, thus when the house is attacked he does his duty of love and faith shines in his soul; similarly, the prince ought to defend his subjects in a just cause'. ${ }^{50}$ For Melanchthon, all human societies had to be based on a natural law which was the same as the ethics of the gospel. There were no special, spiritual commands - like non-resistance which could be used by Catholics and Anabaptists alike to deny the binding force of the natural law. This ruled out Christian pacifism, but it also made just defence not merely permissible but in fact obligatory, a 'duty of love'.

The Loci praecipue theologici offers a summation of many of the themes of Melanchthon's thought; here he explained most fully his belief that the moral law of God and the natural law were fundamentally the same and demanded full obedience from all humans. God imprinted law upon the hearts of men, and when their knowledge of this law was darkened at the Fall he re-iterated it through the scripture, especially the Decalogue. The natural and moral law included both tables of the Decalogue, setting out provision for the worship of God as well as for ensuring justice here on earth. Moreover, Melanchthon went on to insist that this law requires 'perfect obedience, as the Law says (Deut. 6.5) 'Love your God with all your heart'. ${ }^{51}$ The natural and moral law which underpins our political societies demands full obedience, for Melanchthon; there is no space above or beyond that law for acts of supererogation or of specifically religious virtue. Like Luther, 
Melanchthon denied that the moral law was a permissive law, but instead saw it as prescribing and commanding all acts of virtue - which must be done in the right spirit of love and faith.

It was, however, in John Calvin's Institutes of the Christian religion that these ideas were clearly expressed as a coherent whole. Discussing the divine law, Calvin explained that 'when evil is forbidden, its opposite is enjoined', giving as his example the commandment, 'Thou shalt not kill'. This was not merely an injunction to abstain from injury but was in fact a command to help our fellow humans as far as possible. For, Calvin wrote, 'when he [God] so forbids, he, at the same time, demands all the offices of charity which can contribute to his [our neighbour's] preservation.' This moral and ethical law was given by God in the scriptures, most obviously in the Decalogue, but those same commands were also engraved in the minds of human beings and all people were obliged to obey them. ${ }^{52}$ Later in the same chapter Calvin revealed his dependence on the earlier, Lutheran argument, remarking that 'nothing could be more pestilential than the ignorance or wickedness of the Schoolmen in converting the precepts respecting revenge and the love of enemies ... into counsels which it was free to obey or disobey'. Reprising the debate between Luther and the Parisian divines, he added that the 'Schoolmen' had claimed these commands were 'too heavy and burdensome' for most Christians and it was only the monks who were commanded to obey them. ${ }^{53}$ For Calvin - at least in this crucial passage - all actions which were not commanded were prohibited and vice versa; there could be no rights which were not also duties and no actions which were praiseworthy but not obligatory.

The political consequences of this Protestant view of law were made clear in Magdeburg, the Imperial city which held out against the Augsburg Interim in 1550-1. Under siege from Imperial armies, the elders in Magdeburg began to churn out propaganda to stiffen the nerves of their citizens and to seek help from outside. ${ }^{54}$ In these texts, the Magdeburg elders insisted that 'the lesser magistracy is required by God's divine injunction to attempt, together with their subjects to stand up, as far as possible, to such superiors' who violate God's commands. They emphasised that the Council of Magdeburg, as a (lesser) magistrate, had a duty to protect its people and to ensure 
that the laws of God and nature were not violated by the emperor's unjust commands. In the famous Confession and in associated texts, they repeatedly describe the principle of self-defence as an obligation, founded in natural law, stressing the duty of magistrates to take up arms against unjust violence. ${ }^{55}$ Historians have not been especially interested in this aspect of the Confession, preferring instead to explore the Magdeburgers' understanding of who should carry out this defence. ${ }^{56}$ But running like a refrain through the Magdeburg propaganda is the claim that defence cannot simply be licit and permitted but must be a binding duty. The authors of the Confession insisted pious magistrates 'can and must' defend their subjects, that in the case of tyranny no one could doubt that 'by divine law and commandment' such a ruler should be stopped - and that this argument is founded on 'the clear word of God and on the unchanging law of nature'. ${ }^{57}$ Similarly, the Magdeburgers' Answer - one of the next longest pamphlets after the Confession - explained that the magistrate 'is permitted by God, yea, rather commanded in its office, to make use of the forbidden defence against unjust force' ${ }^{58}$

The rationale behind the Magdeburgers' view of law, both natural and divine, was explained in a dedicated part of the theological section of the Confession. Here, under the heading 'on law' there was a critique of those who 'deprave the law, when they make its precepts of not revenging oneself and of forsaking possessions, and similar things into counsels, works of supererogation and of perfection'. These people, it is claimed, place human traditions and monasticism above the law of God. In criticising those responsible for inventing counsels, the Magdeburgers clearly did not want to insist on Christian non-resistance or pacifism but instead to show the obligations which the law, both natural and divine, laid on people, at least in terms of external, ethical action. ${ }^{59}$ Though Luther's first comments on counsels may have implied a commitment to non-resistance, by the 1550s his position had become reversed and the principle of resistance could now be described as a binding duty. In both cases, the Lutheran view of law as command and not as permission underpinned the political claim being made. 
If we now compare the Protestant view of natural law and self-defence with contemporary Catholic, Thomist accounts, the difference is clear. In the wake of the Council of Pisa and then the rise of Lutheranism, Catholic writers had begun to stress that the natural law was given by God to promote (merely) natural ends and to distance it from spiritual power with its spiritual ends. The great defender of Papal power against both Almain and Luther, Cardinal Cajetan, touched on these issues in his works of the 1510s, including his great commentary on Aquinas's Summa theologica which would be taken up and adapted by many later Catholic scholars. ${ }^{60}$ Cajetan was willing to accept, with Almain (and Aquinas), that any community must be allowed to defend itself from tyranny and that if 'there is no recourse to a superior then it is licit to kill a tyrant for the liberty of the people, because this is done on public authority.' Here, Cajetan was not particularly interested in explaining the powers of inferior magistrates, though he was willing to see a community as able to defend itself. He was, moreover, careful to use the language of the licet or permitted, never describing communal defence as obligatory for the community (as Almain had done). ${ }^{61}$ In this way he could distinguish clearly between the community's right to defend itself, and the church's duty to obey the papacy, and thereby open up space for the concept of counsels within the political sphere. And when he explained that individuals were able to do acts which when above and beyond what was required of them, one of the paradigm examples of such supererogatory action was martyrdom, in which the saint did not defend himself. ${ }^{62}$

Cajetan's efforts to disentangle the sphere of natural law (or right) from Christian duty were taken further by Francisco de Vitoria, the Dominican scholar elected to the chair of theology at Salamanca University in 1524. In his influential lectures, Vitoria explicitly distinguished spiritual power from the natural law: natural law simply could not extend beyond the limits of nature but the church's spiritual power came not from nature but from Christ himself. ${ }^{63}$ In his lecture 'on homicide' he argued that a person had the right to kill another where they or their neighbour were in danger, but he was adamant that this right was not a duty, as it was (albeit in different ways) for Almain and Luther. As he saw it, 'not everyone who can lawfully save his own life is obliged to do 
so', for 'oftentimes martyrdom falls under a counsel' - backing up his point with reference to those contested texts Romans 12.19 and Matthew $5.39 .{ }^{64}$ Vitoria wanted to show that there was a sphere of licit action which is nevertheless imperfect and which a person might reject for the sake of a greater, spiritual good or to fulfil a counsel of perfection; unlike the Protestants we have considered, he saw natural law as permissive, at least in some sense.

These Catholic authors did not want to dispute the legitimacy of warfare nor deny that governments had a duty to protect their subjects. But they wanted to create space above and beyond the duties of the civil world, space which allowed for the articulation of spiritual ends, including self-sacrifice, and for an authoritative, coercive Church. Almain had reluctantly acknowledged this space, and in the 1520s Luther and Melanchthon had sought to shut it downsensing a strong connection between a prescriptive concept of natural law and an end to the independent power of the Catholic Church. In the arguments of the next generation, the connection made by Luther had hardened into orthodoxy and would crystallise around the issue of just defence. Drawing on the prescriptive understanding of law set out by Luther, the Protestants in Magdeburg were able to explain their military actions not only as licit defence against unjust violence but as a duty owed to God.

The debate over counsels was a crucial aspect of the formation of political and ethical thought in the sixteenth century. It led both Protestants and Catholics to consider the status of law and to consider how far it obliged human beings, rather than simply permitting particular actions. We have seen that the Protestants appealed to a natural law from which counsels had been excluded, and that their understanding of magistrates' divinely given duty to protect their subjects gained its force from their distinctive reading of God's commands. Luther's critique of monastic vows, of works of supererogation and of the 'sophisters' of Paris had led him to reject even nonresistance as a counsel and to insist upon the commands of the law. This concept of law led later Protestants to elevate the principle that force could be repelled by force from something permitted 
by natural law to a strict obligation, a part of natural and divine law. The right to resist tyranny could also be seen as a religious duty, and the connection between these two concepts was invoked to stiffen the resolve of hesitant Protestants. ${ }^{65}$ The political implications were, however, far reaching, potentially justifying a wide range of actions to counter perceived tyranny or ungodly violence. Indeed, there are signs that by the end of the century some Protestants wanted to return to a concept of natural law which was more permissive, but the connection between Protestant theology and prescriptive natural law persisted, especially among those who saw themselves battling ongoing Papal tyranny. Luther may have dismissed those who defended counsels as trifling sophists, but their ideas - and, even more, his response - would shape the theology and the political thought of the Reformation.

Sarah Mortimer, Christ Church, Oxford OX1 1DP sarah.mortimer@chch.ox.ac.uk

*An earlier version of this article was presented at the Cambridge History of Christianity Seminar and I would like to thank the participants for their comments. I am also grateful to Noah Dauber and the anonymous reviewers of the Historical Journal for their suggestions and advice.

\footnotetext{
${ }^{1} \mathrm{H}$. Höpfl ed., Luther and Calvin on secular authority (Cambridge, 1991) pp. 3-4. The text can also be found in Luther's Works (hereafter LW), 55 vols, (St Louis, MO and Philadelpha, PA, 1955-86); vol 45:2 pp. 75-131, entitled 'On Temporal Power: To What Extent It Can Be Obeyed?'.

${ }^{2}$ For an overview see e.g. R. von Friedeburg and M. Seidler, 'The Holy Roman Empire of the Christian Nation' in H. Lloyd, G. Burgess, S. Hodson eds. European political thought, 1450-1700 : religion, law and philosophy (Yale, 2007) esp pp. 114-20; F. Oakley, 'Christian Obedience and authority, 15201550 ' in J.H. Burns ed. The Cambridge history of political thought, 1450-1700 (Cambridge, 1991). ${ }^{3}$ M. Baylor, 'Political Thought in the Age of the Reformation' in The Oxford handbook of political philosophy (Oxford, 2011) p. 232. J. A. Carty remarks, in a fascinating thesis, that Jesus's teaching in
} 
the Sermon on the Mount 'quickly became a defining political problem of the early Reformation' yet he does not link this to Luther's views on counsels. See his 'Machiavelli, Luther, and the Reformation of Politics', (PhD thesis, University of Notre dame, 2006) p. 181.

${ }^{4}$ For example J. Guy, 'The Rhetoric of Counsel in Early Modern England', in D. Hoak ed., Tudor Political Culture (Cambridge, 1995); J. Rose ed., The politics of counsel in England and Scotland, 12861707 (Oxford, 2016); J. Paul, 'Counsel and Command in Anglophone Political Thought', Ph.D. thesis (Queen Mary, University of London, 2013

${ }^{5}$ Luther's views on counsels have not been extensively discussed but some analysis can be found in works concerned with his theology such as D. Janz, Luther on Thomas Aquinas : the angelic doctor in the thought of the reformer (Stuttgart, 1989) pp. 52-3; B. Lohse, Mönchtum und reformation; Luthers auseinandersetzung mit dem mönchsideal des mittelalters (Göttingen, 1963) pp. 265-7 and 364. In Martin Luther's theology: its historical and systematic development transl. R. Harrisville (Minneapolis, 2011), Bernhard Lohse quotes Luther's reference to the political implications of an erroneous view of counsels on p. 154 but does not link this to his theological discussion of the issue (found earlier, on p. 142). Meanwhile, counsels are not mentioned even in such important studies of Luther's political thought as W. Cargill Thompson, The political thought of Martin Luther (Brighton, 1984); or J. Estes Peace, order and the glory of God. Secular authority and the church in the thought of Luther and Melanchthon, 1518-1559 (Leiden, 2005).

${ }^{6}$ The point is made, albeit briefly, in a number of studies of supererogation, such as David Heyd, Supererogation (Cambridge, 1982) pp. 26-29; G. Mellema, Beyond the call of duty: supererogation, obligation, and offence (Albany, NY, 1991) pp. 44-54. B. Tierney, Liberty and law: the idea of permissive natural law, 1100-1800 (Washington, DC, 2014) offers a broad account of the concept of permissive law but says little specifically about the early sixteenth century or Protestant political thinking; G. Conti, 'Jean Barbeyrac, Supererogation, and the Search for a Safe Religion,' Modern 
Intellectual History, 13:1 (2016): 1-31 shows the continuing relevance of questions of supererogation into the later seventeenth century.

${ }^{7}$ Q. Skinner, Foundations of modern political thought volume II: the Reformation (Cambridge, 1979) p. 335.

$8 \mathrm{~J}$. Witte, Reformation of rights: law, religion and human rights in early modern Calvinism (Cambridge, 2007) p. 23.

${ }^{9}$ See for example G. Burgess, British political thought, 1500-1660 : the politics of the postReformation (Basingstoke, 2009) esp p. 66; and his chapter 'Political Obedience' in U. Rublack ed. The Oxford handbook of the Protestant Reformations (Oxford, 2016) esp pp. 91-2. Also C. G. Shoenburger, 'Luther and the Justifiability of Resistance to Legitimate Authority' in Journal of the History of Ideas 40:1 (1979) pp. 3-20 esp p. 16. Luise Schorn-Schütte's excellent Gottes Wort und Menschenherrschaft: Politisch-Theologische Sprachen im Europa der Frühen Neuzeit (Munich, 2015) discusses the concepts of rights and duties, focusing on connections between them rather than any distinctive nature of rights in the Protestant tradition. Catholic conceptions of rights, liberties and, to a lesser extent, duties have been discussed more extensively; see in particular A. S. Brett, Liberty right and nature: individual rights in later scholastic thought (Cambridge, 1997).

${ }^{10}$ For the context of the tract see H. Schilling Martin Luther : rebel in an age of upheaval transl. $\mathrm{R}$ Johnston (Oxford, 2017) pp. 409-12; M. Brecht, Martin Luther vol 2: shaping and defining the Reformation, 1521-1532 transl. J. Schaaf (Philadelphia, PA, 1990) pp.117-19. For the doctrine of the two kingdoms which Luther developed in this tract see Cargill Thompson, The political thought of Martin Luther.

${ }^{11}$ LW 45:2 pp. 81-2; Höpfl (ed.) On secular suthority pp. 3-4.

${ }^{12}$ Luther's approach to these issues is set out most clearly in A. Raunio, Summe des christlichen Lebens: die "Goldene Regel" als Gesetz der Liebe in der Theologie Martin Luthers von 1510-1527 
(Mainz, 2001). See also V. Mäkinen and A. Raunio, 'Right and Dominion in Luther's Thought and Its Medieval Background' in V. Mäkinen ed., Lutheran Reformation and the law (Leiden, 2006).

${ }^{13}$ Thomas Aquinas, Summa Theologica lla llae Q $40 \mathrm{~A}$ I ad 2.

${ }^{14}$ See for example T. Cajetan, Evangelia cum commentariis reuerendissimi domini domini Thomae de Vio (Paris, 1532) fo. xixr; and J. Mair, In Mattheum ad literam expositio (Paris, 1518) fo. 19v.

${ }^{15}$ Aquinas, Summa Theologica lla llae Q 184, esp. a. 4.

${ }^{16}$ On the case of Grabow see John Van Engen Sisters and brothers of the common life: the Devotio Moderna and the world of the later Middle Ages (Philadelphia, 2008) pp. 212-218 and idem, 'Illicit Religion: The Case of Friar Matthew Grabow', in: R M Karras, J Kaye and E A Matter eds., Law and the illicit in medieval Europe, (Philadelphia, PA 2010) pp. 103-116.

${ }^{17} L W$ vol 51 pp. 9-10, 12-13.

${ }^{18} L W$ vol 31 p. 235.

${ }^{19}$ Luther's own experience as a monk may have been important here; see the fascinating article by Ulrich Köpf, 'Luther als Mönch', Luther: Mitteilungen der Luthergesellschaft 55 (1984), pp. 66-84.

${ }^{20} L W$ vol 44 p. 256.

${ }^{21}$ Ibid. p. 257.

${ }^{22}$ For the relationship between the two Reformers at this time see Estes, Peace, order and the glory of God pp. 58-68; Brecht, Martin Luther vol 2 pp. 104-5.

${ }^{23}$ The 1521 Loci communes are printed in W. Pauck (ed.) Melanchthon and Bucer (London, 1969), quotation from pp. 57-8.

${ }^{24}$ The document is entitled 'Errores excerpti ex probationibus et declarationibus conclusionum Martini Luther ordinis fratrum Heremitarum sancti Augustini' and printed in P. Kalkoff, Luther und die Entscheidungsjahre der Reformation: von den Ablassthesen bis zum Wormser Edikt (Munich, 1917) pp. 194-203, see esp. pp. 198-9. 
${ }^{25}$ Determinatio theologicae facultatis Parisiensis, super doctrina Lutheriana, hactenus per eam visa (Paris, 1521) sig. biiiiv [Illud verbum Xi Matthaei quinto. Qui percusserit in maxillam dextram \&c. Et illus ad Romanos xii. Non vos defendentes charissimi \&c non sunt consilia, sicut etiam multi Theologi errare videntur, sed praeceptum. Haec proposition est falsa, legis Christianae nimium onerativa, \& sanae intelligentiae scripturae adversa.] The document is discussed in J. Farge, Orthodoxy and reform in early reformation France: the Faculty of Theology of Paris, 1500-1543 (Leiden, 1985) pp. $165-9$

${ }^{26} \mathrm{An}$ account of the events surrounding the Council of Pisa and a selection of relevant texts can be found in J.H. Burns and T. M. Izbicki eds., Conciliarism and Papalism (Cambridge, 1997).

${ }^{27}$ Most recently in The watershed of modern politics: law, virtue, kingship, and consent (1300-1650) (New Haven, CT, 2015) pp. 249-50; see also his 'Almain and Major: conciliar theory on the eve of the Eve of the Reformation', American Historical Review, 70 (1964-5), 674-90.

${ }^{28}$ J. Figgis, Studies of political thought from Gerson to Grotius: 1414-1625 (Cambridge, 1907). For example Skinner, Foundations vol I/ pp. 117-23, 176-8; A. Brett, 'Scholastic political thought and the modern concept of the state' in A. Brett and J. Tully eds. Rethinking the foundations of modern political thought ed. (Cambridge, 2006) pp. 130-148; F. Oakley, Conciliarist tradition: constitutionalism in the Catholic Church (Oxford, 2003).

${ }^{29}$ See the translation in J. Kraye ed. Cambridge translations of Renaissance philosophical texts vol 2 (Cambridge, 1997) pp. 13-35, esp. pp. 14-17.

${ }^{30}$ Acutissimi ... Jacobi Almain Senonensis ... expositio circa decisiones quaestionum M. Guillermi Ockam, super potestate summi pontificis (Paris, 1526) 'iure naturali quilibet tenetur servare vitam propriam quantum potest medio licito ... peccat contra legem naturalem qua tenetur servare vitam suam quantum potest' fo. $65 \mathrm{v}$.

${ }^{31} \mathrm{Ibid}$. Gerson is discussed on fos. 65r-v. Brian Tierney emphasises Almain's commitment to selfpreservation in this text in The Idea of Natural Rights (Atlanta, 1997) pp. 236-7. 
${ }^{32}$ Acutissimi ... Jacobi Almain fo. 66r.

${ }^{33}$ Mair, In Mattheum ad literam fo. 19v ['Tenetur plus seipsum diligere quam proximum']

${ }^{34}$ Ibid. fo $21 v$.

${ }^{35}$ Determinatio Theologicae facultatis Parisiensis, under the heading 'De constitutionibus ecclesiae'.

${ }^{36}$ The ongoing importance of the writing of Almain and Mair is also noted in Farge, Orthodoxy and reform p. 103.

${ }^{37}$ Erasmus, Dulce bellum inexpertis in M. Mann Phillips ed. and transl. Erasmus on his times: a shortened version of the 'Adages' of Erasmus (Cambridge, 1967); also R. Adams, The better part of valor; More, Erasmus, Colet, and Vives, on humanism, war, and peace, 1496-1535 (Seattle, 1962).

${ }^{38}$ On Wyclif's pacifism see R. Cox, John Wyclif on war and peace (Woodbridge, 2014).

${ }^{39}$ Höpfl ed., On secular authority pp. 14-15.

${ }^{40}$ Ibid. p. 42.

${ }^{41}$ An account of the incident with the related texts can be found in J. Estes, Whether secular government has the right to wield the sword in matters of faith: a controversy in Nurnberg in 1530 over freedom of worship and the authority of secular government in spiritual matters (Toronto, 1994).

42 Ibid. p. 86.

${ }^{43}$ Ibid. p. 114.

${ }^{44}$ The political background is discussed in J. Whaley, Germany and the Holy Roman Empire. Volume 1, Maximilian I to the peace of Westphalia, 1490-1648 (Oxford, 2012) ch. 4.

${ }^{45}$ The principle can be found in the Digest 43. 16. 1. 27.

${ }^{46}$ Skinner, Foundations, II 201-4. R. Von Friedeburg, Self-defence and religious strife in early modern Europe : England and Germany, 1530-1680 (Aldershot, 2002) pp. 61-2.

${ }^{47}$ D. Böttcher, Ungehorsam oder Widerstand? : zum Fortleben des mittelalterlichen

Widerstandsrechtes in der Reformationszeit (1529-1530) (Berlin, 1991); R. von Friedeburg, Luther's 
legacy: the Thirty Years War and the modern notion of 'state' in the empire, 1530s to 1790 s (Cambridge, 2016) esp. pp. 127-33.

${ }^{48}$ P. Melanchthon, Philosophiae moralis epitome (1538) p. 55 'noticiae divinitus impressae mentibus hominum nobiscum nascentes, hoc est iudicia quaedam de moribus quae sunt quoddam mentis lumen'.

${ }^{49}$ Ibid. p. 58.

${ }^{50}$ The final, 1559, version of the Loci praecipue theologici is printed in Corpus Reformatorum vol 21, quotations from cols 722-23.

${ }^{51}$ Ibid. cols 711-16 ('de lege naturae').

$52 \mathrm{~J}$. Calvin, Institutes of the Christian religion transl. H. Beveridge 2.8.9. On the relationship between natural and divine law in Calvin see e.g. John Helm, John Calvin's Ideas (Oxford, 2004) esp p. 379; I. Backus, 'Calvin's Concept of Natural and Roman Law,' Calvin Theological Journal 38 (2003) pp. 7-26. ${ }^{53}$ Calvin, Institutes of the Christian religion 2.8.56.

${ }^{54}$ On the principles underlying the Magdeburgers' pamphlets see C. Schoenberger, 'The Confession of Magdeburg and the Lutheran Doctrine of Resistance', unpublished PhD thesis, Columbia 1972. More recent accounts of Magdeburg include T. Kaufmann, Das Ende der Reformation: Magdeburgs "Herrgotts Kanzlei" (1548-1551/2) (Tübingen, 2003) and N. Rein, The chancery of God: Protestant print, polemic and propaganda against the Empire, Magdeburg, 1546-1551 (Aldershot, 2008). ${ }^{55}$ Confessio et Apologia Pastorum et Reliquorum Minlstrorum Ecclesiae Magdeburgensis 1550; it was simultaneously published in German as Bekentnis, Unterricht und vermanung der Pfarrhern und Prediger der Christlichen Kirchen zu Magdeburg Anno 1550. Quotation from Confessio sig. Av.

${ }^{56}$ D. Whitford, 'From Speyer to Magdeburg: The Development and Maturation of a Hybrid Theory of Resistance," Archiv für Reformationsgeschichte 96 (2005): 57-80; R. von Friedeburg, "'Confusion" around the Magdeburg Confession and the Making of Revolutionary Early Modern Resistance Theory 'Archiv für Reformationsgeschichte 97 (2006): 307-18. 
${ }^{57}$ Confessio sig. F3v 'non solum posse, sed etiam debere pios magistratus illis [those introducing idolatry] resistere'; sig. Gr that such resistance 'esse iuris \& mandati divini'; Gv-G2r 'sumptum ex manifesto verbo Dei, ex principiis naturae prorsus immutabilibus'.

${ }^{58}$ Der Prediger zu Magdeburgk wahre, gegründte Antwort auff das rühmen ihrer Feinde (Magdeburg, 1551) sig. [Ciiiv] English translation from Schoenberger, 'The Confession of Magdeburg' p. 139.

${ }^{59}$ Confessio sig. Br 'Depravant legem, cum ex praeceptis de non vindicando, de desertione facultatem \& similibus faciunt consilia, opera supererogationis ac perfectionis. Item cum praeferunt opera electitia vitae monasticae, \& alia traditionum humanarum, operibus legis divinae praeceptis.' See also sig Cv.

${ }^{60}$ On Cajetan's thought generally see J. Wicks, 'Thomism Between Renaissance and Reformation: The case of Cajetan' in Archiv Für Reformationsgeschichte 68 (1977) pp. 9-31.

${ }^{61}$ Sancti Thomi Aquinati Opera omnia, iussu impensaque Leonis XIII (Rome, 1882) Comments ad Ila Ilae Q 64 Article 3 (vol 9 p.70).

${ }^{62} \mathrm{~J}$. Wicks (ed.) Cajetan Responds: a reader in Reformation controversy, 1518-1534 (Washington, DC, 1978) pp. 78-9. See also Cajetan's discussion of martyrs in his comments ad lla llae Q 124 Article 5 in Sancti Thomi Aquinati Opera omnia (vol 10 p. 42).

${ }^{63}$ A. Pagden ed. Vitoria: Political Writings (Cambridge, 1991) p. 71.

${ }^{64}$ F. Vitoria, On Homicide, and commentary on Thomas Aquinas: Summa theologiae Ilallae, 64 ed. J.

Doyle p. 94. On Vitoria's thought see also A. Brett, Liberty, right and nature ch. 4 and on his relationship to Cajetan K. Elliot van Liere, 'Vitoria, Cajetan, and the Conciliarists,' Journal of the History of Ideas 58 (1997): pp. 597-616.

${ }^{65}$ See S. Mortimer, 'Law and justice in a divided Christendom' in M. Koskenniemi and M. GarciaSalmones Rovira (eds) International Law and Religion: historical and contemporary perspectives (Oxford, 2017) pp. 25-42. 